\title{
Bridging the gap: the Serbian struggle for good governance
}

\section{Teresa Cierco}

To cite this article: Teresa Cierco (2016): Bridging the gap: the Serbian struggle for good governance, Journal of Contemporary Central and Eastern Europe

To link to this article: http://dx.doi.org/10.1080/0965156X.2016.1219159

Published online: 17 Aug 2016.

Submit your article to this journal $\llbracket$

Џ Article views: 7

Q View related articles $\longleftarrow$

View Crossmark data ¿ 


\title{
Bridging the gap: the Serbian struggle for good governance
}

\author{
Teresa Cierco \\ Faculty of Arts and Humanities, Department of History, Political and International Studies, University of Porto, \\ Porto, Portugal
}

\begin{abstract}
ABSRACT
This article explores the role of the European Union (EU) in the implementation and promotion of good governance principles in Serbia. It is clear that the EU demands on democratisation in the Western Balkan region are crucial in achieving the respect for good governance principles. Even though the membership perspective might be a promising instrument to promote good governance in external countries, the main causal mechanisms have to be identified in order to provide facts for this assumed causality. Conditionality serves in this context both as a EU promising tool to promote good governance and as a theoretical framework to explain causalities between the EU membership perspective and the implementation of good governance principles in Serbia. However, progress in the area can hardly respond to the integration that Serbia aspires to in its relation with the EU. Looking to the European Commission's latest report on the country's progress, there are several internal constraints to the implementation of good governance principles, such as corruption and organized crime. The article aims to uncover Serbia's progress towards good governance principles. The main question is to find out if conditionality is working in this case, and if not, what are the main reasons why not.
\end{abstract}

\section{KEYWORDS}

Good governance; corruption; organized crime; Serbia; European Union

In practice good governance involves promoting the rule of law, tolerance of minority and opposition groups, transparent political processes, an independent judiciary, an impartial police force, a military that is strictly subject to civilian control. A free press and vibrant civil society institutions, as well as meaningful elections. Above all, good governance means respect for human rights.

Kofi Annan, Preventing War and Disaster: 1999 Annual Report on the Work of the Organization

\section{Introduction}

The principles of good governance, namely transparency, participation and accountability, are closely associated with the way public institutions manage their resources and provide their services efficiently, free of abuse or discrimination. Poverty and corruption are often rooted in the malfunction of governments in complying with sound public affairs management criteria (Hofer 2011). Good governance is also about citizens having the possibility to hold decision-makers accountable for their actions and enhancing citizens' participation in public and political life. 
This article explores the role of the European Union (EU) in the implementation and promotion of good governance principles in Serbia. It is clear that EU demands on democratization in the Western Balkan countries are crucial in achieving respect for good governance principles (Panebianco and Rossi 2004, 20).

The EU uses the same set of foreign policy instruments to promote good governance across its external relations: political dialogue, conditionality and assistance. As the democratization of non-member states is both a normative and strategic aim of the EU, good governance is a main element of its foreign policy. It is reflected in its relations with third countries in general, and in the enlargement policy, in particular. Even though the membership perspective might be a promising instrument to promote good governance, the main causal mechanisms have to be identified in order to provide facts for this assumed causality. Conditionality serves in this context both as an EU promising tool to promote good governance and as a theoretical framework to explain causalities between the EU membership perspective and the implementation of good governance principles in Serbia.

However, progress in this area can hardly respond to the integration that Serbia aspires to in its relation with the EU. Looking at the European Commission's latest report on the country's progress, there are several internal constraints to the implementation of good governance principles, such as corruption, lack of independence, transparency and accountability in key institutions and organized crime.

This article aims to uncover Serbia's progress towards good governance principles. The main question is to find out if conditionality is working in this case, and if not, what are the main reasons why not.

The article is divided into three parts. In the first, we present a brief conceptualization of good governance and try to assess under which conditions conditionality is a successful strategy to promote good governance principles. In the second part, we argue that conditionality strategy has some limitations for this purpose. Looking to basic literature and to some EU official reports, there is still a huge gap between how conditionality works at the legal and societal levels. In the third part, we analyse Serbia's path towards the EU and the results of the conditionality strategy regarding respect for and implementation of good governance principles. We then conclude that in Serbia good governance principles are difficult to achieve due to two complex problems: corruption and organized crime. In this part, we use reports from United Nations organizations and non-governmental organizations such as Transparency International, and interviews that were carried out with some representatives of non-governmental organizations in Belgrade in March 2014.

\section{The importance of good governance in transition countries}

Good governance has been considered an important factor in the transition processes that the Western Balkan countries embarked on since the beginning of the twenty first century. ${ }^{1}$ The main objective is to join the EU. Both the research community and the policy-makers dealing with political and socio-economic changes in the region normally use the "good governance" concept to analyse the evolution of the democratization process in this group of countries. This is especially due to the Europeanization process and the generally high level of international involvement in the region (RRPP 2013).

Good governance is essential to democratic consolidation and economic development since it promotes trust in government (RRPP 2013). This concept and its meaning have been 
strongly promoted and supported by several international organizations such as the World Bank $^{2}$ or the Organisation for Security and Cooperation in Europe, and in the last decades (IFAD 1999), by the EU, within the enlargement process, in a first moment regarding central and eastern Europe and since 2000, in the Western Balkan region.

The EU's enlargement policy has been perhaps the most powerful tool in promoting good governance in its neighbourhood (Brozel 2010,9). Accession to the EU requires acceptance of European law (the "acquis"), compliance with the "Copenhagen criteria," ensuring "stable institutions that guarantee democracy, the rule of law, human rights" (European Council 1993), and the participation of citizens in decision-making processes, a fight against corruption and transparency of state affairs (RRPP 2013).

Although this group of countries, with the perspective of EU accession, has already adopted some important and difficult reforms, it is still characterized by high levels of bureaucracy, corruption, informal practices and lack of transparency and accountability of public institutions. The persistent authoritarian and nationalistic values and norms within the societies in question are considered a heavyweight that these countries have to carry in their road towards the EU (Dzihic 2012).

There is no single and exhaustive definition of "good governance," nor is there a delimitation of its scope. The term is used with great flexibility; this is an advantage, but also a source of some difficulty at the operational level. According to the United Nations Human Rights: Office of the High Commissioner:

depending on the context and the overriding objective sought, good governance has been said at various times to encompass: full respect of human rights, the rule of law, effective participation, multi-actor partnerships, political pluralism, transparent and accountable processes and institutions, an efficient and effective public sector, legitimacy, access to knowledge, information and education, political empowerment of people, equity, sustainability, and attitudes and values that foster responsibility, solidarity and tolerance. (UNHR 2012)

We can thus affirm that good governance is the process whereby public institutions conduct public affairs, manage public resources and guarantee the realization of human rights in a manner essentially free of abuse and corruption, and with due regard for the rule of law.

In 2012, the Enlargement strategy of the European Commission identified "good governance, the rule of law, administrative capacity, unemployment, economic reform and social inclusion" as the major challenges for the Western Balkans (European Commission 2012). Moreover, the annual reports of the European Commission, which evaluated the progress of each country regarding the political and economic criteria for accession, emphasize the respect for good governance principles as essential in getting EU support.

The concept of "good governance" was introduced by the EU in 2001 with the document "Governance in the European Union: A White Paper" (European Commission 2001). In this text, the EU articulated five basic principles of good governance: openness, participation, accountability, effectiveness and coherence (European Commission 2001, 10), each of them being essential for the establishment of democratic governance. In fact, all these principles provide the foundation for democracy and the rule of law, and in practice, can be translated into certain tangible things, such as: free, fair and frequent elections; a representative legislature that makes laws and provides oversight; and an independent judiciary that interprets laws (Cheema and Maguire 2002, 8). They also translate into a guarantee of human rights and the rule of law, and transparent and accountable institutions (Cheema and Maguire 2002). Good governance also decentralizes authority and resources to local governments 
to give citizens a greater role in governance (Cheema and Maguire 2002). Finally, good governance ensures that civil society plays an active role in setting priorities and making known the needs of the most vulnerable people in society (United Nations 2014).

The principles of good governance are effective in post-conflict societies as a neutral and practical set of measures meant to advance the rebuilding of nations and to reset a fundamental link between civil society and state institutions (Caluser and Salagean 2007, 14).

Good governance is an important means to achieve larger ends, namely equitable and sustainable development, security and conflict prevention. But we can consider it also as a valuable objective for EU policy as an end in itself, where larger and more representative proportions of citizens benefit from participating in public affairs, institutions are more transparent and accountable, and the rights of individuals are protected, respected and fulfilled in ways that are consistent with international human rights standards (Landman and Larizza 2010,3).

After the white paper, many other EU documents mentioned the importance of good governance. In 2006, the EU identified good governance, democracy and respect for human rights as vital to the process of "sustainable development and as a major objective of EU development policy" (European Commission 2006, 3). The document entitled "Governance in the European Consensus on Development: Towards a harmonised approach within the European Union," asserts that:

in an increasingly globalised and interdependent world, peace and security hang to a great extent on the political will and ability of governments and institutions to pursue policies geared to the rule of law, the protection of human rights, democratic governance, eradicating poverty, promoting sustainable development and reducing the inequalities that lie at the root of the main challenges facing the world. (European Commission 2006, 3)

According to the European Basic Treaties,

the Union's primary strategic goal should be to maintain its values, support and consolidate democracy, the rule of law, human rights and international law principles through external actions. The EU should practice these principles in efforts to promote global governance policies and realise its goals. (Ling 2013, 92)

This was done in 2000, when the concept of good governance (based on human rights, democracy and rule of law) was included in the Cotonou Agreement, "becoming a fundamental element of the relations between the EU and African, Caribbean and Pacific countries and subject to regular monitoring that determined the amount and means of foreign aid administered to these regions" (Ling 2013). Through trade and foreign aid, the EU seeks to export its values by associating trade and development with political issues. In addition, in 2004, when the EU conceived the European Neighbourhood Policy, it expressed the principle that "the privileged relationship with neighbours will build on mutual commitment to common values. The level of ambition of the EU's relationship with its neighbours will take into account the extent to which these values are effectively shared" (European Commission 2004, 3). And, concerning the Western Balkans, this was done through the Stabilisation and Association Process, which was launched in June 1999, and was strengthened at the Thessaloniki Summit in June 2003.

In its external relations, the EU embraces democracy promotion and good governance as a crucial feature of its role in the world. This involves "the rights of citizens on the road to sustainable development" and includes: 
respect of human rights and fundamental freedoms ... support for democratisation processes ... respect for the rule of law ... access for all to an independent justice system ... and a government that governs transparently and is accountable to the relevant institutions and to the electorate. (European Commission 2006, 5)

The EU's focus on the performance of public institutions and issues related to the access to justice and the control of government institutions is also confirmed by the Instrument for Pre-Accession Assistance (IPA) (Council of the European Union 2006). This EU financial instrument aims to strengthen institutional capacity, cross-border cooperation, economic and social development for countries engaged in the accession process to the EU (Council of the European Union 2006). In the case of Serbia, the country benefits from two EU main supports which constitute attractive incentives for its path: politically, the High Representative appointed a Personal Representative based in Belgrade to work closely with the Serbian Government on all political and rule of law issues; financially, there is Serbia's national IPA. In 23 December 2013, the European Commission adopted the 2013 national programme for Serbia under the IPA. "The €178.7 million programme will help Serbia to implement reforms in key areas such as rule of law, public administration, social inclusion, private sector development, transport, environment, energy and agriculture" (European Commission 2013c). These reforms are vital for the country's European integration process, helping Serbia "in the area of rule of law by supporting the implementation of national strategies for the fight against corruption, improving the prison system and strengthening the independence and competence of the judicial system" (European Commission 2013c). EU funds have already helped the country to adopt important steps regarding good governance, such as the National judicial reform strategy (2006), the Reform of the correctional system in Serbia (2005), the National anti-corruption strategy (2005) and its implementation plan from one year later, the National strategy for the fight against organised crime (2009), and the related Integrated Border Management Strategy (2006) and the Customs Risk Analysis and Risk Management Strategy (2008).

\section{Conditionality}

Conditionality is one strong Europeanization instrument that gives the EU significant influence in transferring to the applicant countries its principles, norms and rules, as well as in determining their institutional and administrative structures. It also associates the gradual development of the EU's relations with the particular countries to the accomplishment of political and economic conditions by the latter. As Schimmelfennig $(2005,127)$ stated, political conditionality is "a strategy of reinforcement used by international organisations and other international actors to bring about change and stabilise political change at the state level." In the same context, Smith (1998) presents a wider, more EU-relevant, definition of political conditionality. According to Smith "political conditionality entails the linking, by a state or international organisation, of perceived benefits to another state (such as aid), to the fulfilment of conditions relating to the protection of human rights and the advancement of democratic principles." And, as Schimmelfennig and Sedelmeier (2004) identify it, the strong emphasis on conditionality rendered accession into a predominantly technical and administrative process of rule-transfer.

Since the end of the cold war, the EU has been applying political conditionality and during this time, a qualitative adjustment has been made. Conditionality is no longer based on promises, but rather premised on assessments of performance by the candidate countries. 
This means "compliance is induced not so much by incentives and coercion as through education and teaching by the international institutions and learning at the national level" (Checkel 2000, 5).

As an EU foreign policy strategy for promoting political and economic reforms in third countries, political conditionality can be seen as positive or negative. Positive conditionality corresponds to the promise of a benefit in return for the fulfilment of a predetermined condition and is frequently used in the deliverance of economic assistance, as well as in the perspective of EU enlargement (Cierco 2011, 144). Negative conditionality is understood as a punishment if a precise obligation is absent, and results in most cases in sanctions (Tocci 2008,882 ). So, conditionality can be used to promote good governance by combining appealing rewards with certain conditions of democratic development.

As Reinhard states $(2010,200)$, conditionality as a strategy depends on one basic condition: two actors have to be in place with certain interests. In this case, the Serbian government and the EU have to be capable of acting in general, plus acting rationally on a consistent cost-benefit calculation. According to Janine Reinhard (2010, 200), "the incentives offered by one actor can be either social (national and international prestige and appreciation) or material (financial aid or trade liberalisation), but they have to be of certain attractiveness" for one of the actors which, in this case, is the Serbian government. Reinhard identifies the following as being the main characteristics of conditionality: "conditionality is a top-downapproach acting in a state-to-state constellation; conditionality works on a formal, direct, short-term level; conditionality depends on clear conditions; compliance with these conditions can be observed and measured" $(2010,200)$. But, if conditionality is a "top-down approach in a state-to-state constellation," it can only produce changes at the governmental level, in other words, the democratization process can only be influenced top-down, by governmental elites. As Reinhard $(2010,202)$ concludes in her article, key actors of a democratization process, namely civil society, economic elites, political parties, the administration or judiciary at a local or regional level cannot be reached through conditionality.

Looking at this argument, we can thus affirm that conditionality works when it is necessary to elaborate reforms in the legal frameworks of the justice or the administrative sector. At this level, it is up to the government either to accept, or not, these changes according to the EU orientations and guidance. Taking into account the significant amount of EU legislation that has been absorbed in recent years in important areas such as the justice sector, we can argue that in Serbia, the strategy of conditionality has been functioning at the administrative and government level. However, at the societal level, the situation is completely different. When we observed the implementation and the respect of these legal frameworks by society in a daily basis, conditionality reveals its real limitations, especially in a region like the Western Balkans, or in a country like Serbia. As we are going to argue in the next part of the article, the heritage from the past, the strong influence of ethno-nationalism, the culture, values and the perceptions of society regarding democracy, understood as freedom of the collective, and not as freedom and equality of individuals, continue to challenge the development of democracy and the implementation of democratic values in this group of countries. A change of mentality and culture cannot be reached by a state-centred top-down approach as conditionality. And this is the main problem in the Serbian case. While the legal basis has developed further, the implementation of laws needs to be seriously strengthened and respected by society in general. 


\section{Good governance in Serbia}

The most important prerequisite of good governance is security governance, which assures a framework for the application of all other conditions (Caluser and Salagean 2007, 14). Security problems appear in all post-conflict societies. Problems such as weak state institutions, inability of the legal institutions ${ }^{3}$ to control crime and erosion of the judiciary system are a threat to peace and to the transition processes. Organized crime, for example, challenges the security of individuals and the community, both internally and internationally. Thus, well-functioning legal institutions and governments bound by the rule of law are essential to good governance. Weak legal and judicial systems, where laws are not enforced and non-compliance and corruption prevail, undermine respect for the rule of law, and cause economic degradation (Treisman 2000). Thus, promoting the development of the rule of law, democratic principles and better governance, with an independent, transparent, accountable and efficient judicial and legal system, and a government that applies fair and equitable laws, must be at the centre of any reform process (UNHR 2012). This involves changes to long-standing practices, entrenched interests, cultural habits and social and religious norms.

Although a new institutional framework has been slowly and gradually put in place regarding the fight against corruption and good governance of key institutions, there is still a huge gap in Serbia between established norms and institutions and how things are done in practice. Thus, democratic practices have yet to become consolidated and acquire validity and stability.

Serbia demonstrated its clear orientation towards becoming an EU Member State when it submitted a request for EU membership in December 2009. In March 2012, the European Council granted the status of candidate country to Serbia and, in June 2013, it decided on opening accession negotiations. European integration as a basic strategic-political orientation and as a strategic framework for the overall democratic and economic development of Serbia, implies continuing the European integration process and fulfilling numerous, complex and difficult reforms in key areas of the rule of law, particularly judicial reform and anti-corruption policy, and independence of key institutions (European Integration Office 2011, 11).

For now, Serbia is considered by the European Commission $(2013 a, 4)$ to have a "satisfactory track record in implementing the obligations of the Stabilisation and Association Agreement." In December 2012, the Serbian government adopted an action plan to pursue the findings of the Commission's 2012 progress report and, in February 2013, it approved a National Plan for the Adoption of the Acquis for the period 2013-2016. This replaced the National Programme for Integration for 2008-2012 under which 88\% of the planned legislation was reported having been ratified (European Commission 2013a, 7).

In the last years, the Parliament's work has been made more transparent and it has enacted several important laws aiming at alignment with the EU acquis but, although"the framework regulating the consultation process has been improved," the European Commission deems that its "implementation needs to stepped up" (European Commission 2013a, 8).

Our argument is that the greatest threats to good governance in Serbia come from corruption, organized crime, violence and poverty, all of which undermine transparency, security, participation and fundamental freedoms. New laws in important areas such as the civilian oversight of the security forces, judicial system, fight against corruption and organized crime 
and regarding the human rights and the protection of minorities, have been adopted following the EU instructions. However, although the legislative and institutional framework for the reform of the judicial sector and the fight against corruption and organized crime is in place, the European Commission argues that further efforts are needed to ensure "full implementation of the legal framework and international instruments" (European Commission 2013a, 8).

Overall, in the two last European Commission reports about Serbia's progress towards the EU, the reference to the fact that the implementation of laws in Serbia needs to be seriously strengthened is constant, stating that the problem is not the legislative framework, but its slow enforcement and implementation. One good example is the new law on Public Procurement. Although it was adopted to increase transparency, preventing corruption and conflicts of interest, it needs still to be fully implemented. The same happens in crucial sectors of the rule of law like the justice sector.

Looking at judicial reform in Serbia, it is possible to argue that this is in a good track after the adoption of a new national judicial reform strategy for the period 2013-2018. For the European Commission (2013a, 39), "this strategy is built around the key principles of independence, impartiality and quality of justice, competence, accountability and efficiency of the judiciary." A set of judicial laws and the updating of others (such as the Law on judges, the Law on Public Prosecution, the Law on the High Judicial Council or the Law on Courts Organisation) were adopted in the last years and have contributed to substantive changes in Serbia's judicial system. But, as Vida Petrovic Skero, President of the Supreme Court argued in an interview in 2008:

although an important set of judicial laws has been adopted, they were not implemented, the law on judges has been altered eleven times and the implementation of legal regulations pertaining to the law on Organisation of Courts has been deferred eight times. (Avramovic and Naas 2008)

The judicial reform in Serbia has followed the path that has been pointed out by the EU, however, several problems regarding the independence of the judiciary or the impartiality and accountability of judges still persist. While the attention of the international community to rule of law issues is strong, domestic political support remains precarious. For instance, across the region, the party inclinations of judges play an important role in determining who will be appointed, and there are reports of political interference in the work of prosecutors and judges (Markovich 2008, 523). Problems with the judiciary also include the low level of expertise among judges in issues related to EU integration, and a big backlog of cases (Eriksen and Kalleberg 2009, 34). One less often mentioned challenge is how judges themselves perceive their independence: independence is often seen as a privilege of judges, rather than as a privilege and right of citizens in a democratic state based on the rule of law (Roos in Eriksen and Kalleberg 2009, 34).

The mission of the judiciary is the realization of the principle of constitutionality and legality and the protection of individual rights and interests (Begovic and Mijatovic 2001, 82). The awareness of citizens that judiciary organs do not act legally and that they are prone to influence, leads to the deterioration of legality and social morals. Corruption in the judiciary has, as a rule, a double undesirable result: on one hand, it ruins the judiciary system as a vital element of state authority, and on the other hand, it corrupts the legal functioning of relations in the sphere from which it came to the judiciary.

According to the European Commission (2013a, 40), "the constitutional and legislative framework still leaves room for undue political influence" over the judiciary, in particular as 
regards Parliament's power to appoint judges and prosecutors and its direct participation in the work of the High Judicial Council and the State Prosecutorial Council. ${ }^{4}$ Since "allegations of corruption in the judiciary persist" (European Commission 2013a), both these institutions need to be strengthened and accountable, due to the fact that these are the bodies mandated by the constitution to guarantee the independence of the judiciary in Serbia. ${ }^{5}$ Therefore, while formal institutional and organizational frameworks and capacities are in place, Serbia's performance is not yet considered to be at required European standards. ${ }^{6}$

\section{Two complex problems}

Corruption and organized crime are considered a threat to stability and good governance in Serbia. They are a real obstacle to democratic stability, sound and accountable institutions, the firm establishment of the rule of law and economic development in the area, and as such are a source of major concern for Serbia.

Corruption is an act or acts undertaken with the deliberate intent of deriving or extracting personal and/or private rewards against the interests of the state (Hope 1997, 89-90). Nye $(1967,419)$ sees corruption as "behaviour which deviates from the formal duties of a public role because of private-regarding ... pecuniary or status gains; or violates rules against the exercise of certain types of private-regarding influence." The definition of corruption, in this instance, relates to the duties of public office and hence it is conceptualized in a political context (Heidenheimer 1977). Widespread corruption is a sign that the state is functioning poorly (Rose-Ackerman 1997, 5). It therefore signifies not only a failure of ethical leadership but of governance as well (Hope and Chikulo 1999). The problem of corruption also lies at the intersection of the public and private sectors. Domestic and external private interests wield their influence illegally in order to benefit from opportunities for corruption.

The literature on transitional states identifies two major types of corruption, which hinder democratization: administrative corruption (private payments to help gain favourable treatment) and state capture (illicit payments made by individuals or groups to officials in order to influence various rules and procedures, such as buying of legislative votes and influencing court decisions) (Cohen 2003, 12). This damages trust in institutions, the perceived authority of politicians and the democratic process as a whole.

According to Transparency International (2011), corruption is one of the greatest challenges of the contemporary world, which "undermines good government, fundamentally distorts public policy, leads to misallocation of resources, harms the private sector and private sector development, and particularly hurts the poor." However, Transparency International also recognizes that controlling corruption will only be successful if there is far-reaching cooperation from a wide range of stakeholders, in society at large, including the state, civil society, the private sector, and international institutions.

Serbia was ranked 72nd out of 177 nations on Transparency International's corruption perception list in 2013 (Transparency International 2013). Also, the EU Progress Report on Serbia points to corruption overall as a major challenge and as typically embedded in the state (European Commission 2013c). The problem of "state capture" - that institutions, instruments and the power of the state are being used by special interest groups to further their own particular interests rather than the public good for which they were supposedly elected - is thus an important backdrop to understanding the nature, scope and challenges of corruption in Serbia (European Commission 2013b, 37). According to Pesic (2007, 6), 
"state-capture" in Serbia has a structural character. In collusion with each other, the political and economic elites have created an informal system to protect their interests. ${ }^{7}$

EU funding has supported important improvements in Serbia's institutional framework for fighting corruption: better laws, the establishment of anti-corruption agencies and strategies, action plans for information and prevention activities, and the addressing of conflict of interest issues in public administration. But, also in this case, the big challenge is the genuine implementation of laws. As the representative of a non-governmental organization in Serbia argued, some of Serbia's main problems are "the violation of anti-corruption laws, the lack of sufficient capacities on the part of the supervisory bodies charged with their implementation, and insufficiently transparent decision-making processes". ${ }^{8}$

The new strategy adopted for the period 2013-2018, aims for:

both a structural approach dealing with issues such as good governance, independent institutions, internal and external audit and control, and protection of whistle-blowers, together with a sectoral approach addressing corruption in the most sensitive sectors such as public procurement, urbanism and spatial planning, the judiciary, police, education and health. (European Commission 2013a, 41)

This is considered extremely important because its implementation "will test Serbia's preparedness and willingness to proceed forward" (European Commission 2013a, 41).

Political conditionality from Brussels is important in creating legislation and establishing institutions, but only as an external motivation. The fight against corruption must find roots in the life and feelings of the common people. And it is here that conditionality reveals its limitations. As Duyne $(2013,82)$ argues, "the internal motivation must come from the people: they can either be resigned to corruption, be part of it, or make their dissatisfaction known, for example during elections."

The lack of trust in public institutions such as the political parties or courts destabilized the democratization process. In Serbia, $77 \%$ of the citizens consider the political parties corrupt (UNODC 2011). And, according to Duyne $(2013,83)$, "in the perception of the people little has changed." According to a representative of a non-governmental organization in Serbia, "corruption is a serious concern. It is widespread particularly in public procurement and privatization". 9

Until 2001, Serbia did not have a coherent anti-corruption policy (Fatic in. Kostadinova 2012, 172). Only after Milosevic did the country undertake important steps to improve its governance and Serbian anti-corruption legislation developed in line with European standards (Kostadinova 2012,172). Provisions on corruption were set out in the Criminal Law of the Republic of Serbia and in the Criminal Code (2005), which came into force in January 2006. This entire anti-corruption legislative framework was improved after Serbia's adhesion to the Council of Europe, and to the Group of States Against Corruption (GRECO), both in 2003. Moreover, Serbia became part of the Council of Europe Criminal Law Convention on Corruption and of the United Nations Convention against Corruption in 2005. Several organs, such as the Anti Corruption Council (2001), the Public Procurement Office (2003), the State Audit Institution Ombudsman (2005) and mobile anti-corruption teams were established and the role of the state in the economy was reduced. These all constitute important developments, though they have failed to change people's negative perceptions. According to a TNS Medium Gallup poll from June 2012, almost $87 \%$ of citizens think that Serbian politicians lack the political will to fight corruption because they benefit immensely from it. The most 
corrupt institutions in Serbia, according to one opinion poll, are political parties (77\% of respondents), health care (74\%) and government and judges (69\%) (BTI 2014).

During the last decade, a mixture of some progress and much stagnation can be observed which leads some authors to claim that "there is little interest, both within the government, but also civil society in participating (in the fight against corruption)" (Trivunović 2007, 73). According to Duyne's $(2013,86)$ conclusions, a "sizeable part of the population has personal experience with corruption, which they may consider as a nuisance, but not as the most prominent problem for themselves or society in general." And, although people disapproved of this kind of act, bribes happen in a voluntary manner ( $85 \%$ of the respondents in a Gallup survey admitted to have taken the initiative) (Gallup cited in Duyne 2013, 86). The negative perception of public officials leads citizens to indifference and to believe that "no one cares," not even the government.

To combat this public indifference, the Anti-Corruption Agency ${ }^{10}$ has initiated a public anti-corruption awareness campaign: "was submitted 2112 public authorities' integrity plans and has developed and is applying corruption risk analysis of draft legislation" (European Commission 2013a, 41). In addition, it also increased its activities in the field of training and education, and its cooperation with some stakeholders (European Commission 2013a, 41). Investigations into corruption cases have been stepped up, especially in high-level cases, resulting in criminal charges of former ministers, businessmen and judges (European Commission 2013a, 41).

Another threat to good governance in Serbia is organized crime. Over the decades, organized crime has been conceptualized in terms of groups, networks, as well as "enterprise crime" (Levi 1998). It refers to criminal activities such as production and trade of narcotics, illegal prostitution, trafficking of human beings or human organs, trafficking stolen cars and radioactive materials, and money laundering. The United Nations Convention against Transnational Organized Crime (2004) defines an organized crime group as a "structured group of three or more persons existing for a period of time and acting in concert with the aim of committing one or more serious crimes or offences in order to obtain, directly or indirectly, a financial or other material benefit."

The main goal of organized crime is to acquire profit (Grubac 2008, 29). It is a planned, long-term and jointly profitable activity of a number of persons, which is performed across state borders to that end. Although there is no general consensus on the concept, all agree that it is a special type of criminal offence, an "extremely dangerous, suigeneris and complex form of delinquent behaviour, which undermines the foundations of modern state and the main principles of democratic system" (Grubac 2008, 29-30). Organized crime is established as a system parallel to the state, and it can be marked as an association operating outside control of the public and of the government (Grubac 2008, 30). It is particularly dangerous when it tries to "take over and control main state institutions" (certain ministries, parliament, courts, police), and it undermines citizens' trust in the state (Grubac 2008, 31).

According to Grubac $(2008,39)$, "large-scale organised crime in all its forms emerged in Serbia at the beginning of the 1990s."The dissolution of socialist Yugoslavia, the Croatia and Bosnia Herzegovina civil wars, and the sanctions imposed on Serbia and Montenegro by the international community have contributed to the increase in organized crime (Grubac 2008). To maintain political power, the Milosevic regime "accepted" organized crime as a means of obtaining money and arms for the country. ${ }^{11}$ The interaction or even complicity of authorities with criminal organizations was hardly disguised. Corruption, and misappropriation of state funds were rampant while the population became impoverished (Pesic 2007). Thus, the state 
was fully integrated in crime, and vice-versa. To this purpose, Stojarova $(2007,99)$ argued that "Serbian organised crime lived in symbiosis with the state and both players profited from this symbiosis." Criminal activity is treated as a "normal occurrence" (Grubac 2008, 41). The situation began to change only after the assassination of Zoran Djindjic, whose priority was to fight organized crime and to promote the rule of law in Serbia, in 2003 (RFE/RL 11 March 2013). According to Dallara $(2008,164)$, at this time, "the role of military and paramilitary forces, and their connection with organised crime, emerged with dramatic clarity." Slowly, the raising of awareness on the special danger of organized crime to the general interest of the state began to gain form.

Some improvements were achieved in this particular area. In July 2003, a Special Court on Organised Crime within the Belgrade District Court was established, in order to deal with some cases of drug trafficking, and on Mach 2009 Serbia adopted the National Strategy to Fight Organised Crime. Nevertheless, according to the European Commission report (2013a, 51) "organised crime remains a serious concern in Serbia."

Organized crime threatens the stability of the country. The weak structures of the state encourage the threat of criminal activities, due to the "ease with which criminal organisations are able to penetrate the state and its institutions".12 The level of infiltration by organized crime into state structures threatens democracy, democratic institutions and public confidence (Stojarova 2007, 92). Corruption enables the infiltration of organized crime into society because corrupted political elites do not effectively fight organized crime, due to mutual interests (Stojarova 2007, 92).

According to a EUROPOL report $(2013,12)$, the Balkans are considered to be a well-known route used by organized criminal groups. This report argues that this route has long ago proved to be a low-risk route for organized criminal groups, where the port of Constance in Romania, and the channel Rhine-Main-Danube are the main entries into the EU (Europol 2013, 12).

In conclusion, although some progress in Serbia's path towards the EU, judicial reform and the fight against corruption and organized crime are still identified by the European Commission (2014) as the main problems of the transition process in Serbia.

Good governance in Serbia implies not only having legal frameworks, but also practices of decision-making aligned with European principles regarding reliability and predictability (legal certainty), openness and transparency, accountability, and efficiency and effectiveness. These principles are not simply ideas. They must be embedded in institutions and processes at all levels. Actors in the public sphere should be legally obliged to comply with these principles, which must be defended by independent control bodies, by systems of justice and judicial enforcement, by parliamentary scrutiny and by citizens.

Serbia remains vulnerable to both phenomena of corruption and organized crime. Corruption remains widespread in all sectors. This situation results from "inadequate investigations by police, corrupt judges and politicians, insufficient sentencing and a lack of coordination of anti-corruption efforts". ${ }^{13}$ Although there are efforts to improve the legislation, most of them are instigated from outside, rather than by local governments' awareness of the social and economic cost inflicted by the activities of organized criminals. According to a Serbian judge, "the country needs law enforcement agencies, and needs to create regional networks for fighting organised crime". ${ }^{14}$ Also as the State Secretary of the Serbian Ministry of Internal Affairs Vladimir Bozovic argued:

a successful fight calls for the constitution of an anti-corruption coalition on the level of the entire society which will comprise both the government bodies and the non-governmental 
organisation sector, the church, religious communities and the young, with the support of the media. (In Serbia 2013)

The legacies of the conflicts of the past, which have led to a certain degree of "state capture" by organized crime, still express themselves in a relatively low degree of political stability and a high level of economic crime (Benedek 2010, 10). This means that organized crime has an interest in maintaining the "status quo" as regards this situation. From this it follows that improving the rule of law and good governance are a means of building trust and confidence in citizens.

\section{Conclusion}

Despite all efforts and the growing number of laws and regulations, judicial backlogs, corruption and organized crime, continue to hamper reforms in Serbia, mainly due to the lack of implementation and compliance with existing laws. There is a gap between established norms and institutions, and how things are getting done in practice.

Although law is often an essential first step in reform, there is a long-standing practice in the region of passing a law, often under EU pressure, without considering its connection to life and society or its interaction with other laws. Too often projects focus only on formal legal aspects, without regard to implementation or to the necessary internalization of values or policies that a piece of legislation is meant to promote. Adopting new legislation without enforcement capacity has not only created a mismatch between intentions and real change, but also an incentive to bypass and disregard the law.

Legislative activity took place in the last decade in Serbia, especially after 2003, when Serbia joined the Council of Europe and embraced the EU accession process as a priority. Conditionality has played a crucial role in influencing Serbian legislation in important areas of the state and we can thus argue that it has contributed to build a government bound by the rule of law, which is vital to good governance. But this is a gradual and difficult process, involving changes to long-standing practices, entrenched interests, cultural habits and social norms. Conditionality can contribute to better governance but does not control behaviour or mentalities.

Two of the most complex problems in Serbia, corruption and organized crime, contribute to the lack of trust of the citizens in existing institutions, undermine and erode the existing system of values, and overall, foster disorientation and uncertainty. According to the Eurobarometer EB 79 (2013), majority of Serbs tend to not trust in national political institutions $(67 \%$ do not trust in the national government and $70 \%$ in the national parliament).

For now, the main concern is the effective implementation of these laws. Despite all efforts and the growing number of laws and regulations, the lack of efficiency and independence of key institutions, and the levels of corruption and organize crime continue to hold back reforms and put in danger the sustainability of the reform process. Knowing that the criteria of the EU require prospective members such as Serbia to have institutions that guarantee the rule of law, on paper and in practice, it is central to strengthen compliance and the enforcement of existing laws in order to attain an environment of good governance in Serbia. 


\section{Notes}

1. The Western Balkan countries are: Croatia, Bosnia-Herzegovina, Former Yugoslavia Republic of Macedonia, Serbia, Montenegro and Albania.

2. The use of the term "good governance" was initially articulated in a 1989 World Bank publication entitled "Sub-Saharan Africa, From Crisis to Sustainable Growth. A Long Term Perspective Study."

3. Legal institutions can be defined as rules that govern relationships between different agents of the society. They refer to the institutional framework that underpins contractual relationships in a society and encompasses not only laws and their enforcement, but also norms and values.

4. The independence of the court system is a particular concern throughout the Western Balkans. The threat to this independence comes from several sides. From the state, it is primarily through the control of the budget for the court system, and/or the appointment or termination of judges and prosecutors and finally in exerting political pressure in specific court rulings. From the private sector, it is through the buying or influencing of legislation and/or outcomes in court cases, though this issue seems to be of much less concern in the region than the threat of state interference and influence.

5. The High Judicial Council is responsible for appointment and dismissal of judges. The State Prosecutors' Council provides for and guarantees the independence and autonomy of prosecutors.

6. Interview conducted with a representative of a non-governmental organization in Belgrade (March 2014).

7. For Pesic $(2007,6)$, the "most important 'capturing' agents are the political party leaderships who have seized huge state property including public companies, public offices and institutions for their own interest." And he adds "acting in accordance with the 'state capture system' is highly beneficial to political parties, since it provides them with substantial donations, a way to ensure loyalty from party members, and potentially a competitive edge in elections" (Pesic 2007, 58).

8. Interview conducted with a representative of a non-governmental organization in Belgrade (March 2014).

9. Interview conducted with a representative of a non-governmental organization in Belgrade (March 2014).

10. The Agency was established in January 2010 and is an autonomous and independent state body accountable to the National Assembly of Serbia.

11. As Anastasijevic $(2006,2)$ argued "the regime of Slobodan Milosevic was not only corrupted, autocratic, and criminalised: it was a criminal regime, whose whole security sector was deeply involved not just in war crimes, but also in classic forms of organised crime: drug and weapons trafficking, extortion, kidnappings, and targeted assassinations".

12. Interview conducted with a representative of a non-governmental organization in Belgrade (March 2014).

13. Interview conducted with a representative of a non-governmental organization in Belgrade (March 2014).

14. Interview conducted with a Serbian judge in Belgrade (March 2014).

\section{Disclosure statement}

No potential conflict of interest was reported by the author.

\section{ORCID}

Teresa Cierco (D) http://orcid.org/0000-0002-1424-6621 


\section{References}

Anastasijevic, D. 2006. Organized Crime in the Western Balkans. HUMSEC Working Papers Series. Accessed February 5, 2014. http://www.humsec.eu/cms/fileadmin/user_upload/humsec/Workin_Paper_ Series/Working_Paper_Anastasijevic.pdf

Avramovic, J., and G. Naas. 2008. Mission to Serbia Supports Reformers in Developing New Laws on the Judiciary. Accessed February 10, 2014. http://www.osce.org/serbia/57693

Begovic, B., and B. Mijatovic, eds. 2001. Corruption in Serbia. Belgrade: Center for Liberal-Democratic Studies.

Benedek, W. 2010. “The Human Security Approach to Terrorism and Organized Crime in Post-conflict Situations." In Transnational Terrorism, Organized Crime and Peace-building, edited by W. Benedek, et al. 3-16. Basingstoke: Palgrave Macmillan.

Brozel, T. 2010. The Transformative Power of Europe Reloaded. The Limits of External Europeanization. Working Paper no. 11. Berlin: Freie Universitat.

BTI. 2014. Serbia Country Report. Accessed March 2, 2014. http://www.bti-project.org/reports/countryreports/ecse/srb/index.nc\#chap3

Caluser, M., and M. Salagean. 2007. Good Governance in Multiethnic Communities. Belgium: King Baudouin Foundation and Ethnocultural Diversity Resource Center.

Checkel, Jeffrey T. 2000. Compliance and Conditionality. Arena Working Papers WP 00/18. Oslo: Faculty of Social Sciences, ARENA Centre for European Series.

Cheema, G., and L. Maguire. 2002. Democracy, Governance and Development: A Conceptual Framework. New York: United Nations Public Administration Network.

Cierco, T. 2011. "Human Rights Promotion in Serbia: a Difficult Task for the European Union." Revista Brasileira de Política Internacional 54 (1): 142-158.

Cohen, L. 2003. "Embracing Democracy: Weak States and Institution-building in 'Balkan Europe."' Conference Paper, Center for European Studies, Ottawa, 23-24 January.

Council of the European Union. 2006. “Council Regulation No. 1085/2006 of 17 July 2006 Establishing an Instrument for Pre-accession Assistance (IPA)." Official Journal of the European Union, L 210/82, 86-91.

Dallara, Cristina. 2008. "Serbia: Borderline Democracy?"In International Actors, Democratization and the Rule of Law, edited by A. Magen and L. Morlino, 156-188. London: Routledge.

Duyne, Petrus. 2013. "Serbian Anti-corruption Policy. Welcome to Potemkin's Village?" Filozofija I Drustvo XXIV (1): 81-118.

Dzihic, V. 2012. “Dilemmas of Young Democracies in the Western Balkans 20 Years after Yugoslav Dissolution." In Unfinished Business. The Western Balkans and the International Community, edited by V. Dzihic and D. Hamilton, 11-16. Washington, DC: Center for Transatlantic Relations.

Eriksen, S., and A. Kalleberg. 2009. Promoting Good Governance in the Western Balkans. Oslo: DIFI.

Eurobarometer. 2013. Standard EB79. Accessed March 10, 2014. http://ec.europa.eu/public_opinion/ archives/eb/eb79/eb79_fact_rs_en.pdf

European Commission. 2001. European Governance. A White Paper. COM (2001) 428 Final. Brussels: European Commission.

European Commission. 2004. European Neighbourhood Policy. Strategy Paper. COM (2004) 373 Final. Brussels: European Commission.

European Commission. 2006. European Consensus on Development Towards a Harmonised Approach Within the European Union. COM (2006) 421 Final. Brussels: European Commission.

European Commission. 2012. Enlargement Strategy and Main Challenges 2012-2013. COM (2012) 600 Final. Brussels: European Commission.

European Commission. 2013a. Serbia Progress Report. AWD (2013) 412 Final. Brussels: European Commission.

European Commission. 2013b. Thematic Evaluation of Rule of Law, Judicial Reform and Fight against Corruption and Organised Crime in the Western Balkans - Lot 3. Final Main Report. Accessed March 2, 2014. http://ec.europa.eu/enlargement/pdf/financial_assistance/phare/evaluation/2013_final_ main_report_lot_3.pdf 
European Commission. 2013c. EU to Grant 178.7 Million EUR to Support Key Reforms in Serbia. Press releases database. Accessed February 5, 2014. http://europa.eu/rapid/press-release_IP-13-1311_ en.htm

European Commission. 2014. Serbia Progress Report. AWD (2013) 412 Final. Brussels: European Commission.

European Council. 1993. Copenhagen Conclusions of the Presidency. Accessed January 4, 2014. http:// ec.europa.eu/bulgaria/documents/abc/72921_en.pdf

European Integration Office. 2011. Needs of the Republic of Serbia for International Assistance in the Period 2011-2013. Belgrade: European Integration Office.

Europol. 2013. EU Serious and Organised Crime Threat Assessment - OCTA 2013. Van Deventer: European Police Office.

Grubac, M. 2008. On Organized Crime in General, in UNICRI, the Fight Against Organized Crime in Serbia. Belgrade: UNICRI.

Heidenheimer, A. 1977. "Definitions, Concepts and Criteria of Corruption." In Official Deviance: Readings in Malfeasance and Misfeasance, and Other Forms of Corruption, edited by J. Douglas and J. Johnson, 19-26. Philadelphia, PA: J.B. Lippincott Company.

Hofer, E. 2011. Promoting Good Governance in Serbia. EUprogress, European Partnership with Municipalities. Accessed February 4, 2014. http://www.euprogres.org/blog.php?id=107\&num=11

Hope, K. 1997. African Political Economy. New York: M. E. Sharpe.

Hope, K., and B. Chikulo. 1999. Corruption and Development in Africa. Basingstoke: Palgrave Macmillan. IFAD (International Fund for Agricultural Development). 1999. Good Governance: An Overview. Rome: IFAD.

In Serbia. 2013. Anti-corruption Coalition Has to Be Stronger than Any Political Coalition or Tycoons Bozovic. December 10, 2013. Accessed February 4, 2014. http://inserbia.info/news/2013/12/anticorruption-coalition-has-to-be-stronger-than-any-political-coalition-or-tycoons-bozovic/

Kostadinova, T. 2012. Political Corruption in Eastern Europe: Politics after Communisim. Boulder: Lynne Rienner.

Landman, T., and M. Larizza. 2010. EU Policy Discourse: Democracy, Governance, and Human Rights. Stockholm: International Institute for Democracy and Electoral Assistance.

Levi, Michael. 1998. "Organising Plastic Fraud: Enterprise Criminals and the Side-stepping of Fraud Prevention." The Howard Journal of Criminal Justice 37 (4): 423-438.

Ling, Jin. 2013. "The EU's New Approach to Global Governance." China Institute for International Studies 39 (2): 90-108.

Markovich, S. 2008. Serbia. Accessed February 10, 2014. http://www.refworld.org/pdfid/4865cf5e1a.pdf Nye, J. 1967. Pan-Africanism and East African Integration. Cambridge, MA: Harvard University Press.

Panebianco, S., and Rossi, R. 2004. EU Attempts to Export Norms of Good Governance to the Mediterranean and Western Balkan Countries. Jean Monnet Working Papers in Comparative and International Politics no. 53, 1-25.

Pesic, Vesna. 2007. State Capture and Widespread Corruption in Serbia. CEPS Working Document no. 262/March 2007, 1-35.

RFE/RL (Radio Free Europe/Radio Liberty). 2013. Serbia Marks 10 Years since Assassination of Zoran Djindjic. Accessed June 20, 2014. http://www.rferl.org/media/photogallery/politics-balkandjindjic/24922954.html

RRPP (Regional Research Promotion Programme). 2013. Good Governance from a Cross-sectoral Perspective. Accessed February 4, 2014. http://www.rrpp-westernbalkans.net/en/News/GoodGovernance-in-the-Balkans-Status-and-Perspectives-.html

Reinhard, Janine. 2010. “The EU Democracy Promotion through Conditionality in Its Neighbourhood: The Temptation of Membership Perspective or Flexible Integration?" Caucasian Review of International Affairs 4 (3): 196-213.

Rose-Ackerman, Susan. 1997. The Role of the World Bank in Controlling Corruption. Faculty Scholarship Series. Paper 591.

Schimmelfennig, F. 2005. "The EU: Promoting Liberal-democracy through Membership Conditionality." In Socializing Democratic Norms. The Role of International Organizations for the Construction of Europe, edited by Trine Flockhart, 106-126. New York: Palgrave Macmillan. 
Schimmelfennig, F., and U. Sedelmeier. 2004. "Governance by Conditionality: EU Rule Transfer to the Candidate Countries of Central and Eastern Europe." Journal of European Public Policy 11 (4): 669-687.

Smith, Karen E. 1998. "The Use of Political Conditionality in the EU's Relations with Third Countries: How Effective?" European Foreign Affairs Review 3: 253-274.

Stojarova, Vera. 2007. "Organized Crime in the Western Balkans." HUMSEC Journal (1). Accessed February 5, 2014. http://www.humsec.eu/cms/fileadmin/user_upload/humsec/Journal/Stojarova_Organized_ Crime_in_the_Western_Balkans.pdf

Tocci, Natalie. 2008. "The EU and Conflict Resolution in Turkey and Georgia: Hindering EU Potential through the Political Management of Contractual Relations." Journal of Common Market Studies 46 (4): 875-897.

Transparency International. 2011. Mission Statement. Accessed January 20, 2014. http://transparency. org.au/index.php/about-us/mission-statement/

Transparency International. 2013. Corruption Perceptions Index 2013. Accessed January 31, 2014. http:// www.transparency.org/cpi2013/results

Treisman, D. 2000. The Causes of Corruption: A Cross-National Study. Journal of Public Economics 76 (3): 399-457.

Trivunović, Marjana, et al. 2007. Corruption in Serbia 2007. Overview of Problems and Status of Reforms. Bergen: Chr. Michelsen Institute.

United Nations. 2014. Global Issues - Governance. Accessed February 5, 2014. http://www.un.org/en/ globalissues/governance/

United Nations Convention Against Transnational Organized Crime. 2004. United Nations Convention Against Transnational Organized Crime and the Protocols Thereto. Viena: United Nations.

UNHR (United Nations Human Rights). 2012. Good Governance and Human Rights. Accessed January 4, 2014. http://www.ohchr.org/en/Issues/Development/GoodGovernance/Pages/ GoodGovernancelndex.aspx

UNODC. 2011. Corruption in the Western Balkans. Bribery as Experienced by the population. Vienna: United Nations Office on Drugs and Crime.

World Bank. 1989. Sub-saharan Africa: From Crisis to Sustainable Growth. Washington, DC: World Bank. 